\title{
Motivation and Performance: A Psychological Process
}

\author{
Prof. Shoeb Ahmad \\ Department of Managerial and Financial Sciences, Al Zahra College for Women, Muscat, Oman \\ *Correspondence: Prof. Shoeb Ahmad, Email: shoebahmad09@gmail.com
}

\begin{abstract}
The achievement of a workplace entirely depends on the skill of managers that how to offer a motivating environment to its employees. The performance of a workplace entirely depends upon employee motivation which is a crucial element in creating an amicable environment for producing optimal performance. Employee motivation is highly responsible in stimulating workplace harmony, commitment and overall employee performance at the workplace. It is decisive in relating to long term benefits for the organization. Motivated employees signify staff retention and loyalty towards the workplace which in turn foster growth \& development of business. In the competitive business environment, the biggest challenge for managers is to retain the employees and keep them motivated to perform satisfactorily at the workplace. Equally, it is important that the manager must be aware of the behavioural instinct of employees and of the factors of what possibly motivate them. Individuals can be motivated due to various factors like: leadership, rewards, incentives, etc. and other organizational constituents in which they perform the duties. Keeping in mind these views, the study primarily focuses upon the effects of motivational factors on employees' performance. Subsequently, the study highlights the connection among employee motivation along with performance.
\end{abstract}

Keywords: Motivation, Organizations, Performance, Rewards, Theory X, Theory Y, Psychology

\section{ARTICLE INFORMATION}

Author(s): Prof. Shoeb Ahmad

Received: 21 Jan, 2021; Accepted: 24 Mar, 2021; Published: 05 Apr, 2021; e-ISSN: 2347-4696;

Paper Id: BMN-IJBMR-2021-16;

Citation: doi.org/10.37391/IJBMR.090201

Webpage-link:

https://ijbmr.forexjournal.co.in/archive/volume-9/ijbmr-090201.html

\section{INTRODUCTION}

The key features of a successful organization are the ability to attract, retain and promote skilled employees. Each and every individual in an organization is to be dealt upon differently as everyone has different necessities. For this, an organization needs to actively implement the policies and procedures that motivate the employees. Dissatisfied employees recede to perform satisfactorily and subsequently, their productivity is not at par with organization expectation. Thus, the topmost priority of the management becomes that they safeguard the job satisfaction level of employees and make sure that they are satisfied with their tasks, work environment and the management according to Egan [1]. Without their satisfaction they cannot attempt for the workplace goals. Motivation itself is neither the behaviour and nor the performance, in fact it involves action, in addition to the intrinsic and extrinsic forces that influences an individual performance. Motivation in context of corporate world is the process or a way of encouraging people to perform their tasks to accomplish their individual or organization goals. At present, it has become a widely used terminology and is being consistently used everywhere from a small enterprise to a global empire. In fact, at some point it has become a significant factor that decides the fate of an individual. A person's motivation is a main drive to please a dissatisfied necessity and to accomplish a definite aim. In addition, it may be taken as a technique that activates during a physical or emotional need that accelerates a functioning arranged by a purpose. Motivation enables employees to work hard and to encourage organizations to engage their employees in work to attain a common organizational and employee goal [2]. The objectives can be accomplished if teamwork and collaboration among employees is ensured backed by motivation. To comprehend the basics of motivation, one needs to understand the complexities of human nature. As far as human nature is concerned, every individual likes to be recognized and rewarded for his work. Without appreciation a person cannot be motivated to perform better. Performance is directly related to motivation as higher the motivation, better the performance. There is an urgent need to understand and employ motivational tactics at workplace which also can positively impact the management and leadership.

The term 'motivation' can be referred to as motives that facilitates good performance marked by enthusiasm and willingness of employees toward their work. In fact, employee motivation is considered as a force that works as a catalyst for the employees as a means to achieve set ambitions and goals of the organization. Various subject experts have defined the term motivation according to their own perspectives. Motivation can be defined as "all internal and external driving forces that makes the individual to perform an activity, what determines the limits and forms of activity and which give it its activities oriented towards achieving certain goals" [3]. Motivation includes a group of activities, views, principles, beliefs, along with other factor of interests which are intently associated with each other. Workplace motivation can be simply explained and measured in terms of the extent of intensity, responsibility, and creativeness that an employee of an organization carries to his job.

The main responsibility of management and executives in an 
organization is to get work done efficiently by the workers within the given time limit. For this, the management themselves have to be competent and efficient so that they can recognize the intensity of employee performance along with the lack and flaws. They should also have the ability to appreciate the positive things and rectify the flaws without hurting the employees' self-esteem. In a study Mullins [4] explained that individuals carry their own perceptions, ideals and traits to organizational lifecycle, and when supervised efficiently they may transport significant helps to concerns. The exact evaluation of an employee needs does not give perfect assessment of a setting, as the analysis may misrepresent the authenticity itself in case of individuals. The management can get a better picture of employee needs only by involving themselves completely into employee affairs and sorting out their requisites in reality. Retention of efficient workforce is a significant aspect of an organization as its reputation and standing in the competitive market depends on it. On the other hand, the employees may show loyalty towards the organization if only they are satisfied and motivated with their level of involvement in the running of the organization. Hence, it is pertinent that management and executives identify the factors that actually motivate employees and actively imply them.

\section{METHODOLOGY}

The basic aim of this study is to draw attention towards the motivational elements of organizations and its impact on the performance of employees. The study aims to explore various motivational practices that influence the efficiency and potential of employees in different situation and stages of work-life. The study specifies useful managerial implication for employee motivation and performance in an organization. The study reviews different literatures available, identify core issues and, take up each issue as a keyword to explore the relevant literature. The review is based on secondary data collected from books, journals, and study materials available online. The review aims to add to the extant literature and contribute positively to the relevant field of study.

\section{LITERATURE REVIEW}

The term 'motivation' originated from a Latin word 'movere' which refers 'to move' and motivation is what moves the workers from tiredness to attentiveness [5]. There are numerous empirical evidences from the extant literature that motivation has an impact on organizational as well as employee performance.

In today's complex and ever changing environment, management and the supervisors of the organization are bound to create the type of work environment where employees can feel confident, trustworthy for themselves and have a fair share in decision making authority related to the organizational matters. Motivation is a process that describes an individual's intensity, direction and determination of effort to achieve a goal [6]. Motivation is an inspiration for a group or an individual to produce best results and includes all the levels of desires, needs, wishes and other similar feelings [7]. Managerial psychology has deep knowledge on motivational aspect which may be utilised to improve organizational effectiveness [8]. These factors facilitate the increase in motivation level of an employee which in turn enhances the organizational performance and productivity. Keeping this in line, Robbins \& Judge [9] describe motivation as the processes that explain a person's strength, direction, and perseverance of effort with respect to achieve objectives and goals. In a research Omollo [10] describes motivation as a key factor of a successful organization which helps to continue the work processes in a positive way and help organizations to survive in the long run.

There are three motivation components emphasised in McClelland's theory which are the needs for achievement, power, and affiliation. The three motivation components are executives complete stimulus shapes, i.e. the comparative intensities of these three types of motivation which are vital [11]. Motivation is useful everywhere and this is well known to a manager that how it influences a particular target and ratio of individual's performance concerning to commitment for attaining goal. Researches in the field of motivation argue that the importance of motivation as an educational outcome crops up due to its relationship with organizational achievement and performance in a variety of different sectors $[12,13]$.

The motivation of managers influences the way they perform at job. Hence, it validates that the experiential studies of managers are significant. Job motivation inspires an individual for the initiation of an action that is supposed to effect the achievement of some objectives [14]. The money aspect cannot be considered as the single motivator rather there are some additional motivations that may also assist as motivators [15].

Motivation is a function of three significant factors: effort, organizational goals and needs which is being commonly applied by all the workplaces as they now feel it valuable in their work environments [16]. A study conducted in psychology of total quality management explains that there are nine vital motivational elements as depicted in figure 1 below [12].

- Equity: This aspect is about fairness and shows a balance among inputs \& outputs, perception \& reality and expectation $\&$ rewards.

- Equality: Everybody must be treated equally regardless of status; the belief of equal pay for each individual must be established effectively.

- Consensus: Consensus signifies mutual respect that is extreme and more inclusive than settlement and relies on shared values and social consistency.

- Identification: Motivation all the way through influencing others by way of what we state, act and motivated by others in how we observe and what we consider. 
- Rationality: Rationality denotes presentation of the concept of scientific approach to management and decision making which is extremely influencing.

- Instrumentality: Instrumentality is a technique by which something is stimulated, the agency or means in order to attain an objective.

- Development: Development to achieve goal i.e. through motivation for self-improvement. In this context training education is very critical as it supports the individual and organisation.

- Group dynamics: Clear-cut and positive group motivations are produced owing to individual reliability to the group, harmony and a mutual respect and duty towards achieving group targets.

- Internalisation: Internalisation establishes our view, conviction and performance as well as the most influential and long lasting of the nine motivational elements [4].

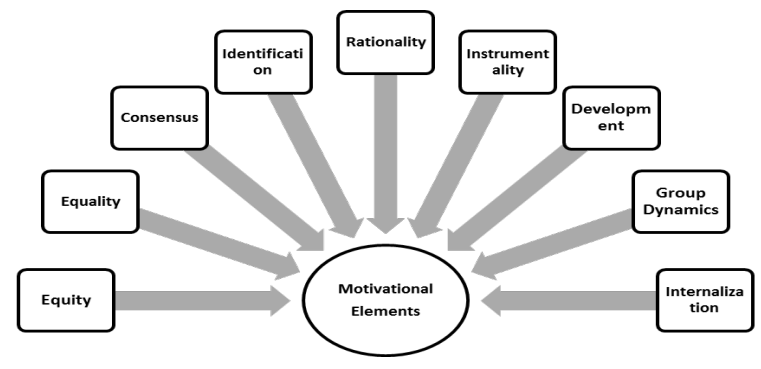

Figure 1: Cartwright's Motivational Elements.

\section{\% 4. CLASSIFICATION OF MOTIVATION}

McCormick and Tifflin [17] categorized motivation into two classes - extrinsic or external motivation and intrinsic or internal motivation. McCullagh [18] in his study concluded with a definition of intrinsic motivation as an individuals' need to feel competent and Proud in doing a work, whereas he stated that extrinsic motivation is related to the performance of an individual in doing a work with a desire to achieve something externally. He further concluded that a person can be motivated both intrinsically and extrinsically. All the external factors related to a job such as salary, work environment, perks, safety and security at work, promotion etc. can be placed under extrinsic motivation banner. Psychological factors of job such as appreciation, recognition, consideration, care, positive reception and respect at workplace accounts for intrinsic motivation components. Both these category of motivation have distinct effect on the employees in terms of their satisfaction and happiness. For example, Employee ' $A$ ' is satisfied with a promotion but not by appreciation because for him, promotion is more valuable. On the other hand employee ' $\mathrm{B}$ ' is happier with appreciation and recognition of his work than some monetary reward. Amabile [19] in his study describes this phenomenon in detail as -"Individuals are intrinsically motivated when they seek enjoyment, interest, satisfaction of curiosity, self-expression, or personal challenge in the work. Individuals are extrinsically motivated when they engage in the work in order to obtain some goals that are apart from the work itself [19].

\subsection{Intrinsic Motivation}

This aspect of motivation refers to a personal orientation to effort and relate to 'oneself'. This always relies on the personal outlook and its effect on an individual differs from person to person and also depends on the situations overall. Wright [20] in the conclusion of one of his studies stated that, "intrinsic rewards provided by the nature or function of the organization may be more important to public sector employees than or compensate for the limited availability of performance-related extrinsic rewards" [20]. Typically intrinsic motivation represent an individual's level of contentment and pleasure in doing a particular job and, has nothing to do with other jobs and activities which may yield external rewards. Intrinsically motivated individual gains inner pleasure in doing a specific work without any desire or longing for any external incentive. In fact this motivation arises from the work itself and the person enjoys the work to the extent of his satisfaction. When employees are motivated without any desire of external rewards or appreciation, it acts as a catalyst for the enhancement of employees' behaviour and performance at work. Hackman [21] concluded in their research that strong intrinsic motivation arises with the creation of three psychological states such as:

- Experienced meaningfulness of the work,

- Experienced responsibility for outcomes of the work, and

- Knowledge of the actual results of the work activities.

\subsection{Extrinsic Motivation}

Extrinsic motivation is fundamentally driven by external forces such as monetary rewards, fame etc. A person who is externally motivated, generally works to give his best only in anticipation of some material gain rather than work for his own contentment. This sentiment is a contrast to intrinsic motivation logic as it is based on the external factors of an individual. Extrinsic motivation is a construct that pertains whenever an activity is done in order to attain some separable outcome [22]. In an organization extrinsic motivation is very important as it determines the actions and behaviour of the employees. The employees are extrinsically motivated to perform better in lieu of the remuneration they receive for their work besides their salary, such as health benefit, education benefit, bonus, commission etc.

\section{¿ 5. EMPLOYEE MOTIVATION THEORIES}

A number of views and theories on employee motivation have been proposed by various researchers based upon their studies which investigated the factors responsible for motivation. All these theories explain the root cause of employee motivation and their positive effect on performance. There are many theories in the field of management that examines work 
motivation and types of motivation, in addition to intrinsic and extrinsic motivation [23]. The complex and varying nature of human needs and desires ultimately creates basic, simple but very positive and comprehensive three-fold category with regard to successful motivation [4]. Practically, all these are independent but satisfying and jointly assist and motivate individuals towards goal achievement. Some of the important and pioneer theories are those of B.F. Skinner's reinforcement theory [24], Abraham Maslow's hierarchy of need theory [25]; Fredrick Herzberg's two-factor theory [26], Vroom's expectancy theory [27], and Adam's equity theory [28]. All these theories are significant as they explain why employees are motivated, and if the reason for motivation is applied properly, could lead to motivated employees which finally contribute to increased productivity in organizations [18]. The aim of understanding and applying motivation theory is to obtain added value through people in the sense that the value of their output exceeds the cost.

\subsection{Maslow's Theory}

Among all these theories, Maslow's theory of 'hierarchy of needs' [25] is the most popular theory on motivation and most of the studies are based on it even today. He categorized employee's needs into five levels in the form of a hierarchy ascending from the lowest to the highest. Maslow concluded that no need can be fully gratified and when a human need is considerably satisfied, it cannot be a motivator. Need is something a person requires and is contented when that particular need is fulfilled whereas, motivation is an effort to satisfy that need [29].

\subsection{Herzberg's Two-Factor Theory}

This is another important motivation theory and is also known as motivation hygiene theory. Herzberg and his colleagues proposed the two-factor model theory of satisfiers and dissatisfiers. In this study Herzberg acknowledged that there are two major elements which could become a driver of job satisfaction in employees; motivational factors and hygiene. He further identified motivators as intrinsic factors which lead to psychological growth and development of a job in context of achievement, recognition, responsibility, advancement and challenges of the job [26].

\subsection{Theory $X \&$ Theory $Y$ of Motivation in the Light of Behaviour Pattern A \& B}

According to McGregor concept to manage people there are two basic ways. Some of the managers who are stimulated by theory $\mathrm{X}$ are narrow-minded and usually they attain inferior performance and outcomes. Whereas, the managers who use theory $\mathrm{Y}$ are broadminded and produce higher performance and outcomes and let people to develop and mature. The managers who follow theory $\mathrm{Y}$ are the competent leaders and are able to meet the psychological contract of employees. Theory $\mathrm{X}$ and $\mathrm{Y}$ are similar to behaviour pattern $\mathrm{A}$ and $\mathrm{B}$ of Chris Argyris. Some of the executives may be XB or YA. The executives $\mathrm{XB}$ possess destructive notions regarding workers, still not only helpful rather support people to be productive in general and are always inclined towards organizational environment. On the contrary, the YA executives monitor people, even if they assume usually that people are motivated and self-contained. In view of [13] bosses apply pattern A actions because they make effort to assist personalities build up with their potentials required for framing an environment wherein they may perform same as YB managers [30].

However, the outcome is difficult to withdraw that Theory $\mathrm{X}$ is inferior and Theory $\mathrm{Y}$ is superior. In contrast, these theories are approaches with regard to employees. Even though, as we know and explain that an executive must focus his/her postulations on Theory Y. Practically, in many circumstances a commanding and managerial actions are needed to support certain characters to grow and mature unless and until they turn out to be productive and self-focused. An individual worker may be encouraged in his work with higher benefits, while other workers may be concerned in a superior and improved working atmosphere [31].

\section{‡ 6. MOTIVATIONAL TOOLS AS PERFORMANCE INDICATORS}

In the presence of positive and clear-cut motivation philosophy and tradition in place, quality, productivity, and service must improve as motivation assists people with regard to achieving goals, gaining well-defined perspective, producing the power for change, developing self-esteem \& ability, as well as managing their growth and assisting others. The success of organization relies on members resulting motivated in order to apply their competencies, and led to perform satisfactory in the proper sectors. Motivation has positive effect on employee mindset and behaviour and in this course, the workplace turns out to be more enjoyable and comfortable where in the workers realise that their work has some valid sense and importance. There are many components which are responsible to increase motivation in an individual. Figure 2 illustrates the motivational tools as performance indicators.

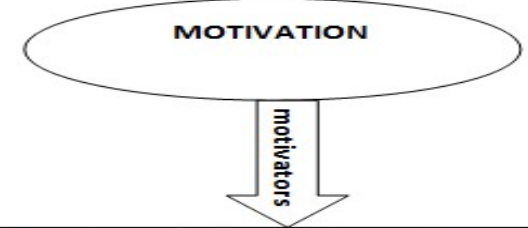

\begin{tabular}{|l|l|l|}
\hline Rewards & Job Enrichment & Training \\
\hline Leadership & $\begin{array}{l}\text { Flexible } \\
\text { Schedule }\end{array}$ & $\begin{array}{l}\text { Participation \& } \\
\text { Empowerment }\end{array}$ \\
\hline Appreciation & Recognition & $\begin{array}{l}\text { Fair } \\
\text { Evaluation }\end{array}$ \\
\hline
\end{tabular}

Figure 2: Motivators as performance Indicators.

\subsection{Rewards}

Rewards are very significant and effective tools of management while making effort to motivate individual or group behaviour aiming to enhance efficiency of organization. Most of the companies use pay, promotion, bonuses and 


\section{Business and Management Research (IJBMR)}

Review Article | Volume 9, Issue 2 | Pages 104-112 | e-ISSN: 2347-4696

recognition etc. to stimulate workforces and to improve their performance. There is need to develop salary structures, special allowances and healthy working conditions in relation to the nature of work, individual performance. In a survey Allen, et al. [32] proposed that various kinds of reward system may carefully supplement diverse plans and are considerably involved in better organizational performance. Numerous surveys have decided that the award scheme must be line up to influence staffs' performing to create it reliable with the organizational plan [33].

\subsubsection{Promotion}

Promotion is a type of non-monetary reward where an employee is moved up in position or rank in his career in an organization. Promotion plays an important role in motivating employees as everyone wants to climb the ladder up in their career and enjoy a high status. A solemn desire to be promoted motivates the employee and inspires to perform better at work. Koech [34], asserts that promotion motivates employee in multiple ways- enhances their self-assessment, satisfies their recognition need, helps achieve goals and boost up their career, as they work in places that provide opportunities for growth. A promoted employee is highly motivated and prepared to meet the challenges of the job. The peer group of the promoted employee is also motivated to perform better in anticipation of their promotion. Though promotion is a performance indicator, point to mention is that it should be fair and aptly rewarded to the deserving person upon his merit, without any bias or any partiality. This is necessary as undeserved promotion may de-motivate other employees.

\subsubsection{Pay increment}

Monetary reward may be contemplated as an instrumental orientation to effort and involves elements, for instance- wage, peripheral benefits, pension privilege, material goods apart from safety. The conventional wisdom is that workers respond to monetary incentives-Pay them more and they will work harder. Employees look forward to some or the other form of monetary reward in return of their service. This reward may be in the form of fixed monthly salary, hourly wages or other types of financial return. Any increase in these monetary incentives highly motivate the employees as money is important for everyone since they can buy the basic needs of the daily lives. Chien-Chung [35] observed that when employees are given periodic pay raises either as promotion benefits, annual increments etc., they are motivated. Monetary increments expedite the performance and productivity of employees. Although Lindner [36] recognizes monetary incentives as unimportant and having less value for motivating people, various organizations use this as a major factor to motivate their workers at all levels. In some organizations, management rewards their employees by incentives to finish a project or a work under deadline.

\subsection{Appreciation \& Recognition}

Appreciation for one's work generates a feeling in an individual's mind that what he/she is doing is meaningful and important, hence respected by peers and bosses alike. This impression makes a person feel good and worthy, about their work and their accomplishments which accelerates their motivation positively. Any type of appreciation of a work done by peers, managers, supervisors, team leaders and the employer can be termed as recognition. Recognition can also be referred to as a means to express gratitude or admiration for the extra effort applied by an employee to complete a work or a perfect job done to achieve the goal, by an employee in an organization. Recognition at all cost, encourages the individual employee or a group in two ways - to perform perfectly and keep on enhancing their performance. This approach of recognized and appreciated employees inspires other employees also, and hence recognition becomes precursor of motivation. Recognition, either formal (written remarks and events) or informal (oral), has been the most cost efficient way to strengthen needed actions for performance inside an organization. Still, when recognition is acting in isolation of compensation and equity rewards, it's frequently loses much of its appeal [37].

\subsection{Fair Evaluation}

Fair evaluation of employees based upon their achievements of individual and group performance and, their skills is very necessary for the growth and development of organizations. Employee motivation is positively influenced by fair evaluation. If the evaluation of employees in organization is unfair and unjust, it would lead to their de-motivation which in turn will affect their performance. Treating employees with fairness and respect at work is not only mandatory but in the long run, it can generate positive economic result for both the employee and the organization. "A large and growing body of empirical evidence from laboratory and field experiments, surveys, and observational data, as well as neuroeconomic research, suggests that workers' perceptions of fairness and trust are also key drivers of their work effort" [38].

\subsection{Leadership}

Leadership is the ability for persuading thing completed in the proper way. With the aim of achieving these goals, the leader must acquire the employees' faith and enable them obey him. Leaders have potential to motivate others and hold significance to leadership efficacy as that of leader's proficiency to convey. A good leadership always has the capability to harness the full potential of an employee performance on a positive note and direct it towards organizational productivity. If a leader is properly skilled and has the talent to inspire others who are responsible to influence his work the leader will be taken as a successful and efficient leader [39] and will support certain change in an enterprise.

\subsection{Job Enrichment}

Job enrichment practices make the job itself motivational as the employee becomes dissatisfied and frustrated by routine tasks. Enrichment supports to lessen the emotion that a duty is repetitious or suggests no career opportunity. Job enrichment is an essential function of fascinating, stimulating, and holding talented persons, especially where task is repetitive or tiring [40]. The employees get an opportunity to develop psychologically and experienced in a job otherwise, failing job 
enrichment practices there is much possibility of inferior and lower output, poor attitude, absenteeism and high turnover, etc.

\subsection{Staff Training}

Training enables employees to learn skills and business strategies from other sectors. Employees welcome the opportunity to sharpen their skill sets and develop their position in the organization and according to Ahmad [41], the new employee offers more influence on competency building processes and human resources practices. As a result, a welltrained and adaptable workforce can be prepared. In a research Al-Madi, et al. [39] stated that training of staff is a chief strategy for motivating workers. Training increases required skills in employees which make sure that employees are fully motivated to make contribution concerning organization's objectives [40].

\subsection{Flexible Working Schedule}

The transformations in economy, technology, social and daily life of prevailing situations have heightened the appreciation flexible working provisions in the workplace. The execution of flexible working hour plan enables employees to carry out their tasks in a relaxed, calm way. Consequently, the motivational level of the employees increases as they do not feel any form of stress or strain in their workings. Further, allows the employees to balance their responsibilities and family issues at home. The flexible working hours plan permit employees to concentrate on multiple roles in at present cutthroat working environments [42].

\subsection{Participation and Empowerment}

Workers participation and empowerment is concerning the involvements of the workers in supervision, policymaking and taking into account the goals and the strategies of the workplace. Workers participation encompasses employers motivating employees to help in managing business practices. This is also acknowledged as worker's involvement. Workers participation involves employers identifying individual worker' ideas and opinions. In order to realise workers that employers regard them as exceptional and effective in managing the organization.

Employee participation is a new concept in industrial democracy and one of the means of employee empowerment [43]. Employee involvement is an empowerment technique wherein workers participate in dealings that was usually set aside for employers. A survey made by Sun, et al. [44] discovered that staff involvement is certainly linked with total quality management (TQM) backgrounds and perfections in business functioning. The key roles are to stimulate and to develop employee relationship and obligation. There are no exact procedures to develop involvement.

Empowerment of workers has been favoured as a mean to enhance motivation [45]. In a study Thomas \& Velthouse [23] outlined that empowered employees are usually explained as self-motivated and dedicated people who feel accountable to accomplish qualitative effort. By a number of studies, it is evident that workforces with high-level empowerment motivation hold superior degree of job motivation, which similarly results in improved organizational output and functioning $[23,46]$. Workers participation and empowerment are two features that are not to be ignored because it plays vital role in perception, dedication and understanding. Thus, there will be a less possibility opposing to changes and not to be appreciated by the management. If the work teams are extremely motivated and loyal towards the organization, then higher levels of development and effectiveness can be attained by the organization. Fully motivated, convinced and committed employees with positive goals will participate to enriched organizational productivity that leads towards better rewards.

\section{RELATIONSHIP BETWEEN EMPLOYEE MOTIVATION AND PERFORMANCE}

Employee motivation and performance has taken the centre stage of research studies in recent times. How an organization prepares itself and work through to motivate its employees, is the topic of utmost concern in both public and private sectors. Performance of an employee can be referred to as the work he or she does. If a work is done, it is said that he or she performed and if the work is not done then it is said, he or she didn't performed. Performance can also be termed as readiness of an employee to do a particular work according to the requirement. Motivation can be defined as an organizational process, which inspire employees to invest their best efforts, skills and performance for the benefit the organization as a whole. It also gives them real motives to realize desires and needs. Motivation enhances the performance and capabilities of a person which further increases the efficiency of organization.

The topic motivation is of utmost importance whenever it is considered in context of performance of an individual. Bishop [47] conducted research on the employee performance and concluded that reward and recognition of performance of an employee affects employee productivity. Employee performance is influenced by motivation because motivated employees work with more effort which ultimately improves the performance [48]. Work performance of the employee depends on the consistency of subjective (motivation, skills) and objective (working conditions) performance factors. The employee performance is strongly influenced by their motivation.

The success and growth of an organization rest on the skill of superiors to offer a motivating situation to its workers. There is a great challenge before the managers to retain the staff as motivated and exercising their duties in the workplace properly. At this stage it is essential for a manager to be aware with the behaviour of each and every employee and, simultaneously what aspect may be useful to motivate each one independently in order to attain the goals. A researcher Joseph [49] concluded that by realising workforces' needs, 
superiors can identify what rewards to utilize to influence the workforces. The aim of many organizations is to offer assistance from motivating employee performance in the place of work by encouraging a successful setting for both the organization and the workforces. Employee motivation has a powerful effect on the effectiveness of an enterprise [50]. The success of the organization relies upon members being influenced to utilise their skills and guided to perform competently in the proper areas. Motivated employees are innovative, self-directed and goal-oriented as they always look for better ways to achieve a goal. They are capable to produce qualitative work with highest efficiency and productivity [51]. If the workers are not focused properly it eventually affects performance. This involves low motivation, lack of positive team spirit, and deprived sense of belonging, considering individuals devalued and poorly recompensed. The scholar Mullin [52] assert that motivation reflects the expectation of a person in relation to his emotional needs that directs an individual to achieve his goals in a distinct manner. The conclusion can be drawn that the conceptual framework built upon around motivational constructs stick to the basic idea that individual needs or expectation arises from the performance level of a person that he or she implies to achieve the desired goals satisfactorily. It is also evident that both extrinsic and intrinsic motivation can convincingly influence human's behaviour and encourage them to carry out specific actions, and enhance their performance as depicted in figure 3.

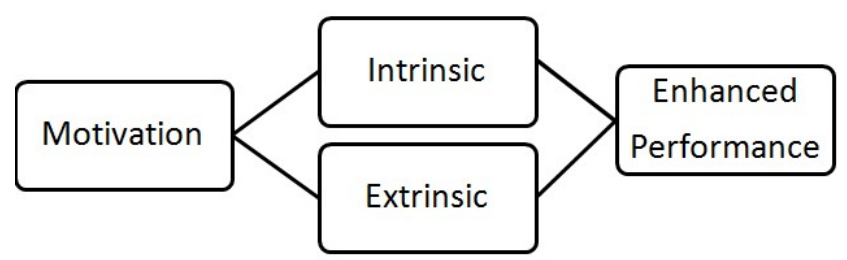

Figure 3: Relationship between motivation and performance.

Whenever we talk about the organizational performance it's not only the capital and financial resources that contributes in goal achievement but the human resource as well that makes a distinction [53]. The organizations, irrespective of size, marketplace, and technology, aspire to be productive prosperous and look after for continuous growth in spite of cut-throat business enterprise. The plans and strategies must be improved and rightly executed with the proper use of all efficient means with the aim of achieving those goals. The roles of motivated manager is to direct organizational members and produce estimated results incorporating: recruitment and selection, training and development, performance appraisal, job security, career growth, work-life balance, pay fulfilment, role, team working, involvement and communication, challenge and self-sufficiency. These are the key HR plans and strategies that act to motivate employees and ensure them to be skilled. In their study Porter \& Lawler [54] concluded that exerted effort should be sufficient to achieve the desired performance level.

Motivation supports the management to be creative and accountable for their actions and executing their roles and fulfil their functions. In addition, assists them in using business resources properly. Motivation enables managers to promote their employees towards their jobs in the right direction and right time. Many of the scholars have exhibited that inspired and stimulated employees accomplish the work gracefully than depressed ones that leads to profit growths [55].

\section{CONCLUSION}

The discussion and empirical review suggests that employee motivation plays an important role in enhancing employee and organizational performance which is linked to the success and goal achievement of an organization. The extent and strategies employed to motivate the workers largely determine their attitude and commitment towards their job. Motivated and contented employees in the organization stay the highly complicated issue of any innovative enterprise. The workers who are inspired as well as motivated feel right, appreciation and accomplishment. The most important aspect is that the employees feel satisfied and motivated at their work. The motivation and enthusiasm of working staffs can be attained throughout the empowerment and inspiration of employees. Motivated and contented employees care for an improved level of innovation, improved quality of work, and an improved level of efficiency. Besides, they are inclined to develop friendly relations and efficient teamwork.

Employee motivation at workplace is contemplated as a significant instinct as it causes effort concerning work-related actions, i.e. eagerness of employees to devote efforts towards achievement of a goal. A motivated employee exhibits complete enthusiasm and zeal towards the job and is determined to achieve both the personal and organisational goals.

\section{RECOMMENDATION}

Organizations need to employ motivational strategies as a continuous process in their organizational plan to ensure smooth services and effective performance. Motivational incentives should include both monetary and physiological components. Management should pay more attention in identifying the motivators as performance indicators and ensure fair evaluation of employees. Motivational strategies should be periodically evaluated and updated accordingly. Organizations are required to set up monitoring systems to evaluate the needs of employees at each and every level aiming to develop plans for employees' growth and development. Additionally, to value employee perceptions about the working environment under which they perform their duties. Effective training programs and feedback techniques are essential to retain individuals on job by building motivation and a healthier workplace with reference to the quality and techniques applied. Right appreciation of better work performance and opportunities to growth should be viewed as a useful and valuable approach for motivation satisfaction.

\section{REFERENCES}


[1] Egan, J. (1998) Rethinking construction. Department of the environment, transport and the regions.

[2] Elvina, S., and Chao, Z. L. (2019) A Study on the relationship between employee motivation and work performance. IOSR Journal of Business and Management, 21(3): 59-68.

[3] Duica, A. (2008) Management. Editura Bibliotheca, Targoviste.

[4] Mullins, L. J. (2005) Management and Organizational Behaviour (7th Ed.). UK: Prentice Hall. 88(431): 1052-1058.

[5] Mohsan, F., Nawaz, M. M., Khan, M., Shaukat, Z., and Aslam, N. (2004) Are employee motivation, commitment and job involvement inter-related: evidence from banking sector of Pakistan. International Journal of Business and Social Science, 2(17): 226-233.

[6] Page, L. (2008) Do not show me the money? The Growing popularity of nonmonetary incentives in the workplace. American Journal of Economics, 93-96.

[7] Shah, K. and Shah,P. J. (2010) Motivation.

[8] Stone, D. L. (2010) Creating knowledge that makes important contributions to society. Journal of Managerial Psychology, 25: 192-200.

[9] Robbins, S. P., and Judge, T. A. (2008) Organizational Behavior 13th edition. UK: Prentice Hall.

[10] Omollo, A. P. (2015) Effect of motivation on employee performance of commercial banksin Kenya: A case study of Kenya Commercial Bank in Migori County. International Journal of Human Resource Studies, 5(2): 87-103.

[11] Andersen. J. A. (2018) Managers' Motivation Profiles: Measurement and Application. Sage Open, 8(2): 1-9.

[12] Cartwright, J. (1999) Cultural Transformation, Financial Times. UK: Prentice Hall.

[13] Dobre, O. (2013) Employee motivation and organizational performance. Review of Applied Socio- Economic Research, 5(1): 53-60.

[14] George, L., and Sabapathy, T. (2011) Work Motivation of Teachers: Relationship with Organizational Commitment. Canadian Social Science, 7(1): 90-99.

[15] Tella, A., Ayeni, C. O., and Papoola, S. O. (2007) Work Motivation, Job Satisfaction, and Organizational Commitment of Library Personnel in Academic and Research Libraries in Oyo State, Nigeria. Library Philosophy and Practice, 9(2): 1-17.

[16] Nduro, M. (2012) The Effect of Motivation on the Performance of Employees at GT Bank Ghana.

[17] McCormick and Tifflin, J. (1979) Industrial Psychology. New York: George Allen and Unwin.

[18] McCullagh, P. (2005) Sport and exercise psychology lecture. Cal State University, East Bay.

[19] Amabile, T. M. (1993) Motivational Synergy: Toward New Conceptualizations of Intrinsic and Extrinsic motivation in the workplace. Human Resource Management Review, 3(3): 185201.

[20] Wright, B. E. (2007) Public Service and Motivation: Does mission Matter? Public Administration Review, 67(1): 54-64.

[21] Hackman, J. R. and Oldham, G.R. (1980) Work Redesign. Readings, MA: Addison-Wesley.

[22] Ryan, R. M. and Deci, E. L. (2000) Intrinsic and Extrinsic motivations: Classic definitions and new directions. Contemporary Educational Psychology, 25: 54-67.
[23] Thomas, K. B., and Velthouse, B. A. (1990) Cognition Elements of Empowerment: An 'Interpretive' Model of Intrinsic Task Motivation. Academy of Management Review, 15: 666-681.

[24] Skinner, B. F. (1953) Science and human behaviour. New York: Free Press.

[25] Maslow, A. H. (1954) Motivation and personality. New York: Harpers \& Brothers.

[26] Herzberg, F., Mausner, B., \& Snyderman, B. B. (1959) The Motivation to work. New York: John Wiley \& Sons.

[27] Vroom, V. H. (1964) Work and Motivation. New York: Wiley.

[28] Adams, J. S. (1965) Injustice in Social Exchange. In: Berkowitz, L. (Ed.). Advances in experimental Psychology. New York, US: Academic Press.

[29] Aldag, R. J. and Kuzuhara, L. W. (2002) Organizational Behavior and Management: An Integrated skills Approach. South Western: Thompson Learning.

[30] Hersey, P., Blanchard, K.H., and Johnson, D.E. (2001) Management of organizational behavior. Leading human resources (8th Ed.). Upper Saddle River: Prentice Hall.

[31] Tietjen, M. A., and Myers, R. M. (1998) Motivation and job satisfaction. Management Decision, 36(4): 226-231.

[32] Allen, R.S., and Helms, M.M. (2006) Linking strategic practices and organizational performance to Porter's generic strategies. Business Process Management Journal, 12(4): 433-454.

[33] Sohail, M.S., and Al-Ghamdi, S. M. (2012) The Relationship Between Strategy, Reward and Organizational Performance: An Empirical Investigation. Middle-East Journal of Scientific Research, 11(10): 1463-1471.

[34] Koech, P. M. and Namusonge, G. S. (2012) The Effect of Leadership styles on organizational performance at State Corporations in Kenya. International Journal of Busienss and Commerce, 2(1): 1-12.

[35] Chien-Chung, L. (2003) Explorations in achievement motivation, presented at Annual Meeting of the American Psychological Association. Washington, DC, US.

[36] Lindner, J. R. (1998) Understanding Employee Motivation. Journal of Extension, 36(3): 1-8.

[37] Wilson, T. B. (2003) Innovative Reward Systems for the changing workplace. US: McGraw Hill, Inc.

[38] Falk, A. (2014) Fairness and Motivation. IZA World of labour.

[39] Al-Madi, F. N., Assal, H., Sharafat, F., and Zeglat, D. (2017) The Impact of Employee Motivation on Organizational Commitment. European Journal of Business and Management, 9(15): 134-145.

[40] Choudhary, S. (2016) Job enrichment: A tool for employee motivation. International Journal of Applied Research, 2(5): 1020-1024.

[41] Ahmad, S. (2014) Team in Its Contexts, Nature, Structure and Effectiveness. Middle East Journal of Management, 1(3): 213223

[42] Ahmad, A. R., Idris, M. T. M., and Hashim, M. H. (2013) A Study of Flexible Working Hours and Motivation. Asian Social Science, 9(3): 208-215.

[43] Uma, M. H. (2015) Employee Participation: A Tool of Motivation and High Productivity. Pacific Business View International, 8(3): 99-102. 
[44] Sun, H., KeeHui, I., Tam, A., and Frick, J. (2000) Employee involvement and quality management. The TQM Magazine, 12(5): 350-354.

[45] Kaplan, R.S. and Norton, D.P. (1996) The Balanced Scorecard: Translating Strategy into Action. Boston, US: Harvard Business School Press.

[46] Koberg, C.S., Boss, R.W., Senjem, J.C., and Goodman, E.A. (1999) Antecedents and outcomes of empowerment. Group and Organization Management, 24(1): 71-91.

[47] Bishop, J. (1987) Recognition and rewards of Employee Performance. Journal of labour Economics. 5(4): 36-56.

[48] Azar, M. and Shafighi, A. (2013) The effect of Work Motivation on Employees' Job Perfromance. International Journal of Academic Research in Business and Social Sciences, 3(9): 432445 .

[49] Joseph, O. B. (2015) The effect of employees' motivation on organizational performance. Journal of Public Administration and Policy Research, 7(4): 62-75.

[50] Paul, E. (2017) 10 ways to improve Employee Motivation.
[51] Boundless Management. (2017) Employee Needs and Motivation.

[52] Mullins, L.J. (2010) Management and Organisational Behaviour (10th Ed.). Harlow, FT: Prentice Hall.

[53] Rida, N., \& Siddiqui, D. A. (2019) Impact of Motivation on Employees Performance in Pakistan. Business Management and Strategy, 10(1): 1-22.

[54] Porter, L.W., and Lawler, E.E. (1968) Managerial Attitudes and Performance. Illinois: Irwin-Dorsey.

[55] Matthew, J., Grawhich, and Barber, L. K. (2009) Are you Focusing both Employees and Organizational Outcomes? Organizational Health Initiative at Saint Louis University, 1-5.

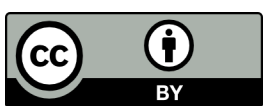

(C) 2021 by the Prof. Shoeb Ahmad. Submitted for possible open access publication under the terms and conditions of the Creative Commons Attribution $(\mathrm{CC}$ BY) license (http://creativecommons.org/licenses/by/4.0/). 